\title{
3-D Cell Culture Systems in Bone Marrow Tissue and Organoid Engineering, and BM Phantoms as In Vitro Models of Hematological Cancer Therapeutics-A Review
}

\author{
Dasharatham Janagama * and Susanta K. Hui * \\ Department of Radiation Oncology, Beckman Research Institute, City of Hope National Medical Center, \\ Duarte, CA 91010, USA \\ * Correspondence: jdgoud@hotmail.com (D.J.); shui@coh.org (S.K.H.); Tel.: +62-6218-0556 (D.J. \& S.K.H.)
}

Received: 6 September 2020; Accepted: 29 October 2020; Published: 9 December 2020

\begin{abstract}
We review the state-of-the-art in bone and marrow tissue engineering (BMTE) and hematological cancer tissue engineering (HCTE) in light of the recent interest in bone marrow environment and pathophysiology of hematological cancers. This review focuses on engineered BM tissue and organoids as in vitro models of hematological cancer therapeutics, along with identification of BM components and their integration as synthetically engineered BM mimetic scaffolds. In addition, the review details interaction dynamics of various BM and hematologic cancer (HC) cell types in co-culture systems of engineered BM tissues/phantoms as well as their relation to drug resistance and cytotoxicity. Interaction between hematological cancer cells and their niche, and the difference with respect to the healthy niche microenvironment narrated. Future perspectives of BMTE for in vitro disease models, BM regeneration and large scale ex vivo expansion of hematopoietic and mesenchymal stem cells for transplantation and therapy are explained. We conclude by overviewing the clinical application of biomaterials in BM and HC pathophysiology and its challenges and opportunities.
\end{abstract}

Keywords: bone and marrow; bone marrow organoids; BM phantoms; biomimetic 3-D scaffolds; hematological cancer; tissue engineering; drug resistance

\section{Introduction}

The bone and marrow (BM) are complex and vital tissues responsible for the support, production, and maintenance of hematopoietic stem cells (HSCs), which differentiate into myeloid and lymphoid progenitor cells and their lineages. Various cell types are involved to maintain the HSC niches. To restore the damaged BM tissues, efforts are made to reconstruct the BME niches in vitro mimicking in vivo conditions. Synthetic and natural biocompatible and biodegradable materials, cells, growth factors, and tissue engineering technologies are used to fabricate 3-D scaffolds to mimic the natural BM physiology and functions. Similarly, the HC environment-mimicking 3-D scaffolds are important for understanding the cancer biology and physiopathology in vitro, and for evolving better therapeutics. The xenograft animal model for cancer drug testing is widely used [1,2]. However, a non-animal model of biomimetic 3-D scaffolds not only complements the existing system in practice, but is also cost-effective and convenient [3]. Compatible tissue engineering potentially complements existing cancer models to ultimately lead to advances in cancer prevention, early detection of aggressive cancer, diagnosis, and treatment. Only sporadic and scattered literature is available on bone marrow tissue engineering (BMTE) and hematological cancer tissue engineering (HCTE). Various biomimetic scaffolds are in use for reconstruction of the BM niche. Co-cultured hematopoietic stem cells with other BM component systems model the BM niche. The organoids grow rapidly and cost effectively facilitating direct testing of a drug or combination of 
drugs to predict clinical response from patient. The hematological tumor organoids are proven to be more sensitive or resistant to chemotherapy drug or combination of drugs and radiation. We review the state of the art in the fields of BMTE and HCTE and envisage dramatic transformations in stem cell and hematological cancer research and therapeutics.

\section{Materials and Methods}

A review was made by searching criteria including "Bone marrow," "Cancers," "Leukemia," "Myeloma," "Lymphoma," "Scaffold," "Biomimetic materials," "Transplantation," and "Chemotherapy" for the past 6 decades in various web-based sources such as PubMed, MeSH, Medline, Google Scholar, and others.

\section{Results}

Interest in BMTE and HCTE has been growing for the past 6 decades as evidenced by published articles (Figure 1). The use of scaffolds has accelerated since 1985, indicating the importance of BMand HC-mimetic 3-D scaffolds in BM and HC research.

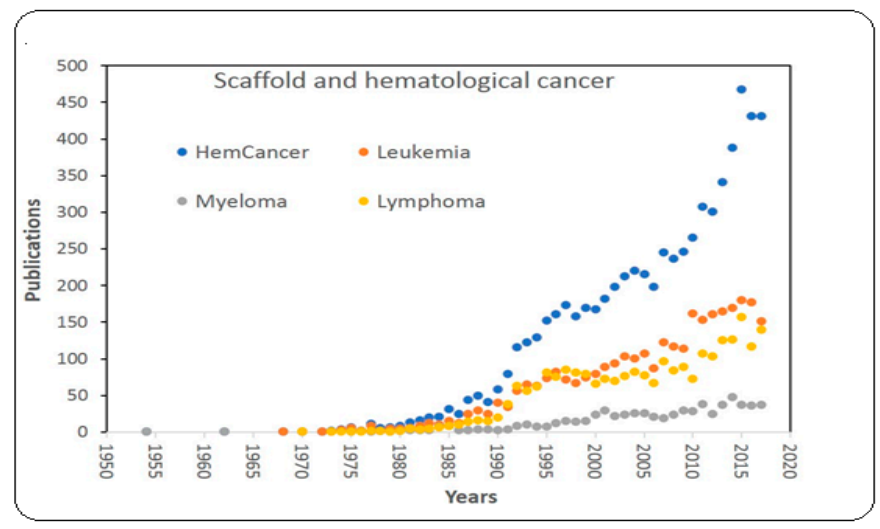

Figure 1. Hematological cancer data visualization: Published articles on BMTE with respect to hematological malignancies such as leukemia, lymphoma, and myeloma.

The organisms with regenerative capability regenerate the damaged tissue or whole organ on their own, without intervention of any external aid [4,5]. The advantages of 3-D culture systems replicating these features are cell-cell interactions and accurate representation of cyto-architecture for tissue regeneration. The concept of TE involves a triadic interaction of cells, scaffolds, and regulatory signals, leading to the formation of the BM or HCs tissue in a 3-D scaffold in vitro with in vivo conditions (Figure 2).

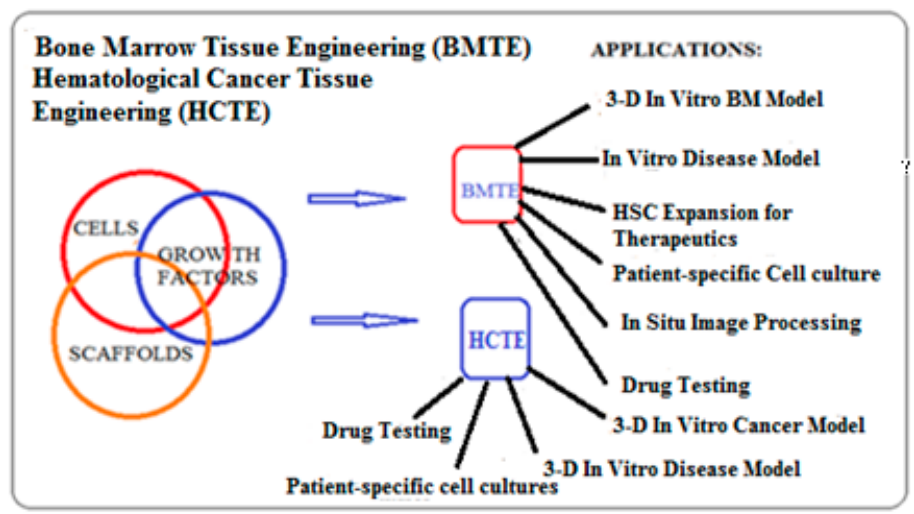

Figure 2. Triadic interaction of cells, growth factors, and scaffolds in BMTE and HCTE.

The advent of novel synthetic and biological polymer materials facilitate fabrication of 3-D architectural bioscaffold constructs with specific parameters, such as biodegradability, biocompatibility, surface morphology or porosity, and material composition, to promote cell proliferation and growth 
mimicking in vivo condition [6,7]. Interactions of HSC, mesenchymal stromal cell (MSC), and HC dynamic environments were studied to understand HSC maintenance and HC physiopathology in the BM environmental niche.

\subsection{Bone Marrow Microenvironmental Niches}

The bone consists of cortical bone, cancellous bone, the periosteum, the endosteum, and articular cartilage (Figure 3). The cortical bone exhibits hierarchical structural organization with osteon, Haversian canals lamella, collagen fibers, collagen fibrils, and non-collagens molecules that are in association with the collagen molecules [8,9]. It is divided into three regions, namely the endosteum, central marrow, and periosteal regions on the basis of the cell types and surrounding structural composition. The multipotent MSCs, bone-lining cells (BLC), osteoblasts, osteocytes, macrophages, and osteoclasts are involved in BM maintenance and remodeling in endosteum. The central marrow is composed of HSCs and progenitor cells (HSPC). These cells are embedded in a meshwork of structural proteins constituting the soft extracellular matrix (ECM). It provides structure and a biochemical platform for HSPC cells to interact and function [8-11]. The perivascular niche is highly vascularized fibrous connective tissue. It is a site of homing for mesenchymal cells, where they differentiate into various cell types such as adipocytes, osteocytes, chondrocytes, and endothelial and neuronal cells [12].

\subsubsection{Interactions of Various Cell Types to Maintain HSC Niches}

Several BM cells and molecules are key players responsible for regulating the hematopoietic niche. The majority of HSCs are confined to the endosteal region and interact with a number of cells, such as MSCs, the nestin-expressing MSC population (nestin ${ }^{+}$MSC), the CXCL12-abundant reticular (CAR), and macrophages that influence HSC survival and functions. It has been demonstrated that MSCs enhance the engraftment of hematopoietic stem cells in an autologous mouse transplantation model [13], and influence differentiation of HSCs [14]. Perivascular endothelial, Schwann, and sympathetic neuronal cells promote HSC maintenance and dictate HSC fate [15]. BM mononuclear phagocytes are reported to help in promoting the maintenance and retention of HSCs [16,17]. Lipid rafts, the glycoprotein microdomains, play a role in signaling processes that could enhance the responsiveness of HSPC to homing $[18,19]$. Several cell types and molecular interactions are involved in the maintenance of BM niches. BM homing ligands include E- and P-selectin, VCAM-1, annexin II, CXCL12, and Kit ligand. N-cadherin, annexin I, osteopontin (OPN), Ang1, BMP4, thrombopoietin, and connecxin 43 are some of the endosteal ligands. ECM interactions and intercellular adhesion lead to cell morphogenesis. The complex signaling pathways regulate HSC development from hemogenic endothelial cells (HEC) through endothelial-to-hematopoietic transition (EHT), pro-HSC and pre-HSC [20].

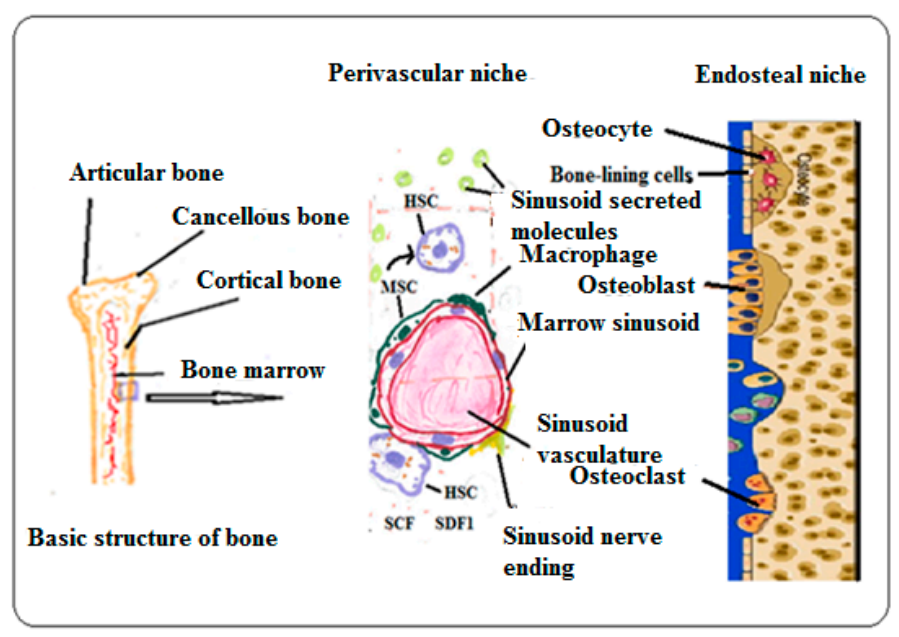

Figure 3. Schematic of structural composition of BM and the cellular interactions. 
3.1.2. Therapeutic Radiation and Chemotherapy Damage Hematopoietic Stem and Progenitor Cells (HSPC) and Recovery Strategies

Therapeutic radiation and anticancer chemotherapy drugs inadvertently damage the HSC niche and pose immense challenges for treating patients while protecting the BM niches. As radiation therapy damages HSC, MSC transplantation rescue has been in practice for the past 50 years to improve HSC recovery with the support of MSC. Radiation accelerate differentiation ability of MSC due to increased oxidative stress [21]. MSCs are resistant to radiation, which is attributed to ataxia-telangiectasia mutated (ATM) protein phosphorylation, activation of cell-cycle checkpoints, double-strand break repair, and the antioxidant capacity for scavenging reactive oxygen species (ROS) [22,23].

\subsection{Biomimetic 3-D Scaffold for Bone Marrow and Hematological Cancer Niches}

The in vitro reconstruction of the $\mathrm{BM}$ and $\mathrm{HCs}$ niches requires a thorough understanding of the natural $\mathrm{BM}$ and HCs microenvironments and the properties of BM and HCs mimicking materials. Bone is primarily composed of calcium hydroxyapatite with trace elements, collagen protein, and water, which provides mechanical support structure for protecting bone marrow and maintain bone and marrow homeostasis. The components of the endosteum, central marrow, and perivascular niches of the BM artificially built to mimic the structures and functions of the BM. BM cells (e.g., HSC, MSC, osteocyte, osteoblast, osteoclast etc.) in scaffold used to investigate cellular function such as mineralization and HSC maintenance. Incorporation of fat cells in bone marrow further allowed to investigate the association of bone, fat, and hematopoietic stem cells. Furthermore, inclusion of hematological cancer cells within the scaffold bone marrow, provides an important tool to test and optimize new drugs. Table 1 provides a brief summary of various aspects scaffolds that are reported earlier. Table 2 provides biomimetic 3-D in vitro bone marrow and cancer models.

Table 1. Comparative constituents of natural BM and synthetic scaffolds to reconstruct and replicate the BM microenvironment for transplantation and regeneration.

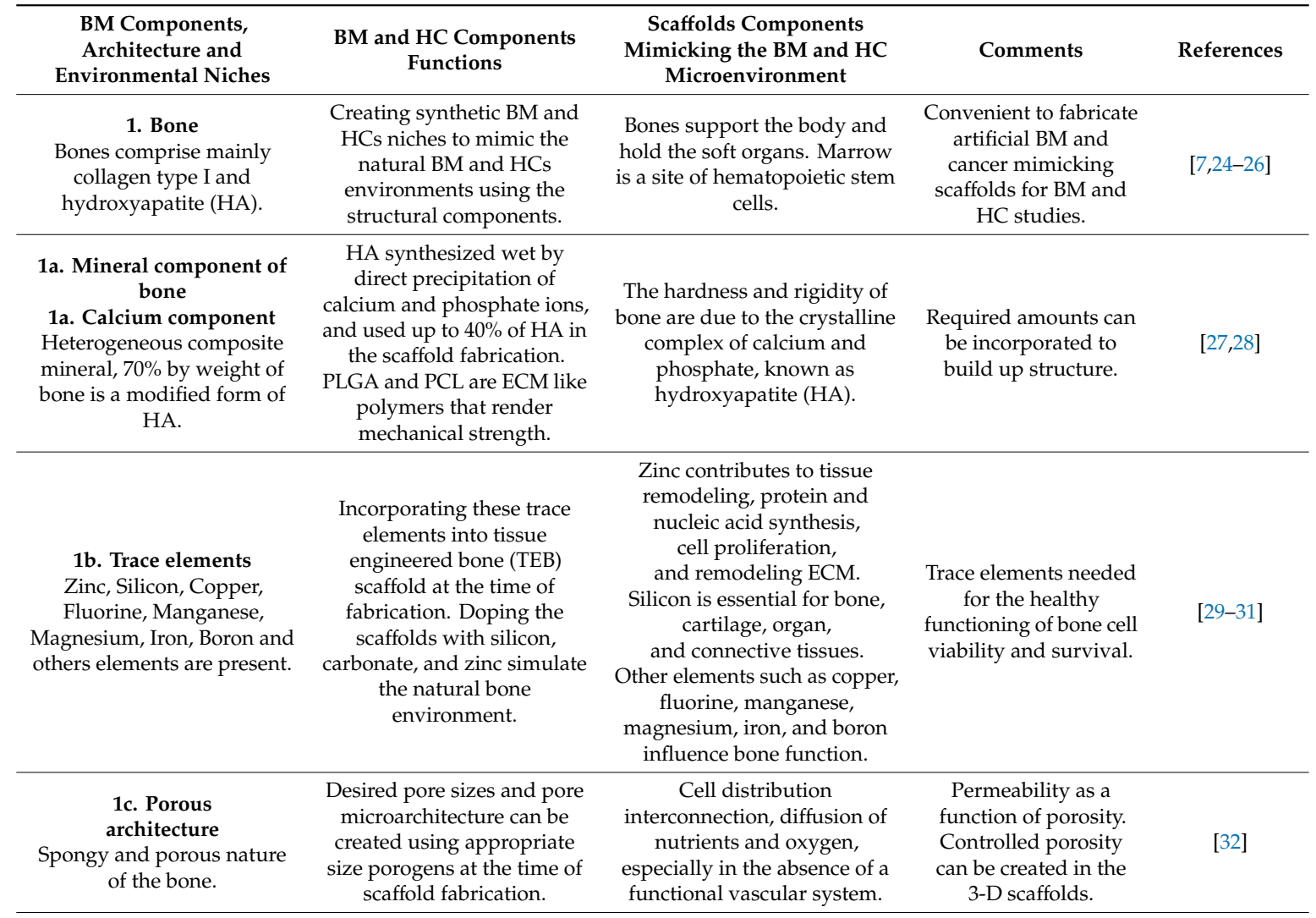


Table 1. Cont.

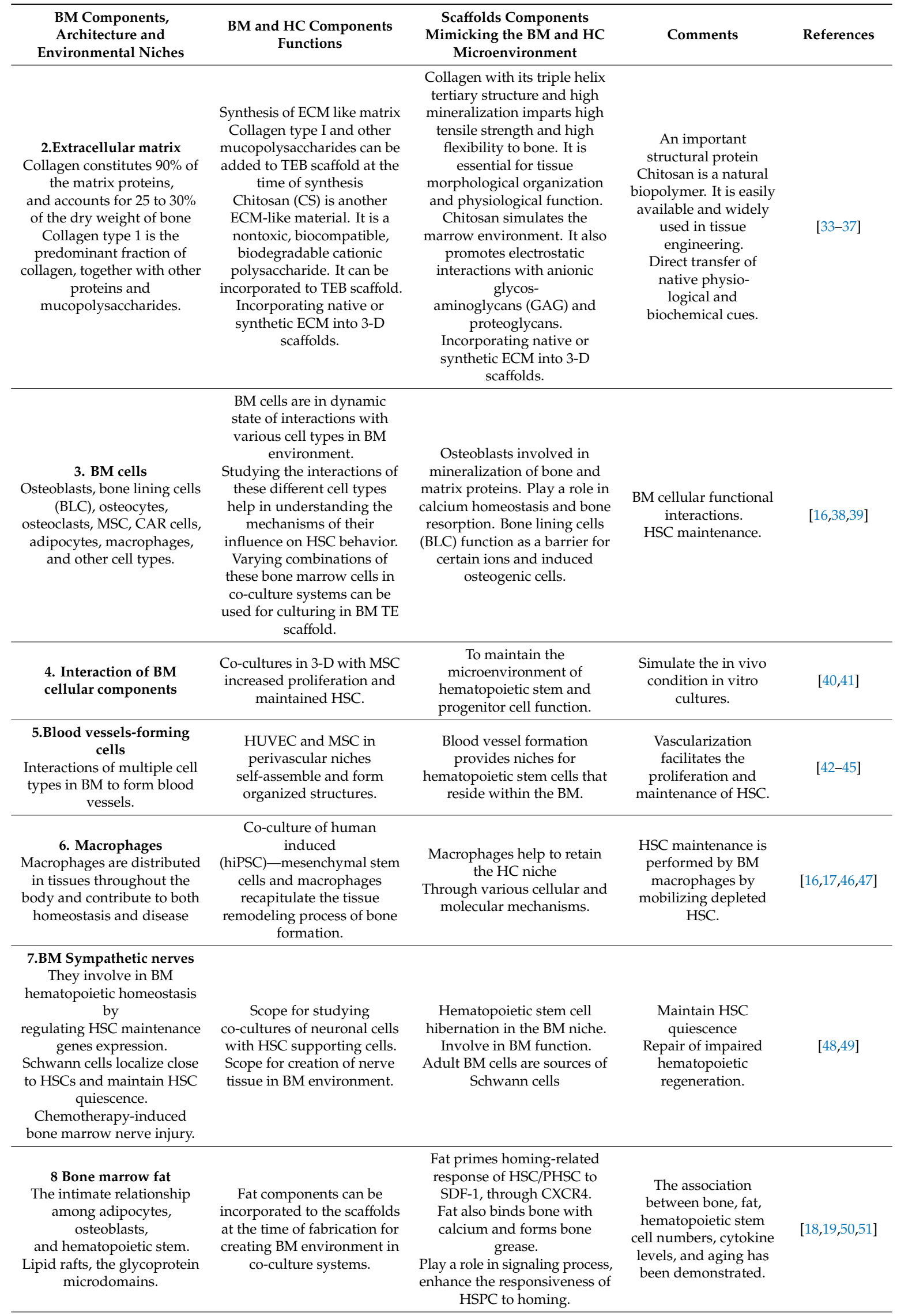


Table 1. Cont.

\begin{tabular}{|c|c|c|c|c|}
\hline $\begin{array}{c}\text { BM Components, } \\
\text { Architecture and } \\
\text { Environmental Niches }\end{array}$ & $\begin{array}{c}\text { BM and HC Components } \\
\text { Functions }\end{array}$ & $\begin{array}{c}\text { Scaffolds Components } \\
\text { Mimicking the BM and HC } \\
\text { Microenvironment }\end{array}$ & Comments & References \\
\hline $\begin{array}{l}\text { 9. HSC cellular stress } \\
\text { Oxidative stress and } \\
\text { hypoxia. }\end{array}$ & $\begin{array}{l}\text { Study of these conditions } \\
\text { and induced effects of } \\
\text { radiation and cytotoxic } \\
\text { chemotherapy in 3-D } \\
\text { scaffold. }\end{array}$ & $\begin{array}{l}\text { Understanding the damage } \\
\text { caused by external agents to } \\
\text { the biology of HSC. }\end{array}$ & $\begin{array}{l}\text { In vitro model of HSC } \\
\text { cellular } \\
\text { Stress. }\end{array}$ & [52] \\
\hline $\begin{array}{c}\text { 11. Hematopoietic } \\
\text { malignancies } \\
\text { CLL, ALL, CML, AML, } \\
\text { MML leukemia and multiple } \\
\text { myeloma }\end{array}$ & $\begin{array}{l}\text { Fabrication of BM and } \mathrm{HC} \\
\text { environments mimicking } \\
\text { 3-D scaffolds. }\end{array}$ & $\begin{array}{l}\text { BM and cancer in vitro drug } \\
\text { testing models. }\end{array}$ & $\begin{array}{l}\text { In vitro disease } \\
\text { model. }\end{array}$ & [56-59] \\
\hline
\end{tabular}

As shown in Table 2, biomimetic 3-D scaffolds are fabricated for creating a microenvironment of various cellular components, including the ECM and vascular systems, with the required physical characters of native tissue.

Table 2. Biomimetic 3-D in vitro bone marrow and cancer models.

\begin{tabular}{ccc}
\hline 3-D Scaffold & Materials & Methods \\
\hline Solid Scaffold & $\begin{array}{c}\text { PLGA, PCL, PGDA, PVA and other } \\
\text { polymers, fats, minerals, } \\
\text { and microelements. }\end{array}$ & $\begin{array}{c}\text { Solvent casting and porogen leaching, } \\
\text { gas foaming, freeze-drying, electrospinning, } \\
\text { and 3-D scaffold printing. }\end{array}$ \\
\hline Hydrogel & $\begin{array}{c}\text { Hyaluronic acid, Chitosan, Alginate, } \\
\text { Collagen, Gelatin, Agarose, and others }\end{array}$ & Gel casting and use of molecular cross-linkers. \\
\hline Matrigel & Basement membrane extract. & Gel casting. \\
\hline Biocomposite scaffold & polymers, cells, growth factors. & $\begin{array}{c}\text { Bioprinting using ink-jet, laser, valve, } \\
\text { and acoustic based. }\end{array}$ \\
\hline Scaffold-free systems & $\begin{array}{c}\text { No scaffold material required. Delivery } \\
\text { of cells and active biomolecules. }\end{array}$ & $\begin{array}{c}\text { Magnetic levitation and self-assembly } \\
\text { hanging drop method for spheroid formation. }\end{array}$ \\
\hline
\end{tabular}

\subsection{Porosity}

In the 3-D architecture of the scaffold, porosity and pore sizes play an important biophysical role. Interconnections of the pores facilitate circulation of nutrients and exchange of gases, thereby diminishing hypoxia in in vitro and in vivo conditions. The pores also support cell function with respect to attachment, migration, and proliferation. Kuboki et al. demonstrated in a rat ectopic model that pores in hydroxyapatite particles are required for osteogenesis [33]. It has been reported that the optimum pore size is $5 \mu \mathrm{m}$ for neovascularization, 100-350 $\mu \mathrm{m}$ for regeneration of bone, and 40-100 $\mu \mathrm{m}$ for osteoid in growth. [60]. A minimum of $\sim 100 \mu \mathrm{m}$ pore size is essential for cell migration and transport, and capillary formation in the bone; pore sizes $>300 \mu \mathrm{m}$ are required for enhanced new bone and capillaries formation [34]. Pore sizes generated in different fabrication methods are given in Table 3.

The pores of closed, open, blind, and through pore types can be created. The pores are created by conventional gas foaming [61,62], $\mathrm{CO}_{2}$-water emulsion templating [63], dense gas $\mathrm{CO}_{2}+$ cross-linker [64], porogen leaching [65], freeze-drying [66-71], and electrospinning methods [72,73]. As shown in Figure 4A, round pores are created in the polymer scaffold using sodium bicarbonate $\left(\mathrm{NaHCO}_{3}\right)$ which generate $\mathrm{CO}_{2}$ gas in a mild acid solution [61]. In this method, the pores created are of heterogeneous sizes depending on the size of the gas bubbles emerging from the polymer slurry. In the solvent casting, casting/particle leaching method, the desired porogens are dispersed into a polymer solution and subsequently leached out by immersing the scaffold in a selective solvent, resulting in the formation of a porous network in the scaffold (Figure 4B). In this method, controlled pore sizes can be generated. Interconnected porous nonlinear filament 3-D scaffolds are fabricated by an electrospinning method of forming ECM mimicking nonlinear fibers under electro static forces (Figure 4C), and hydrogel is introduced into the stacks of nonlinear scaffolds for cell proliferation and 
growth $[73,74]$. These polymer fibers can be used for making nanocomposite scaffolds using other polymers and hydrogels.

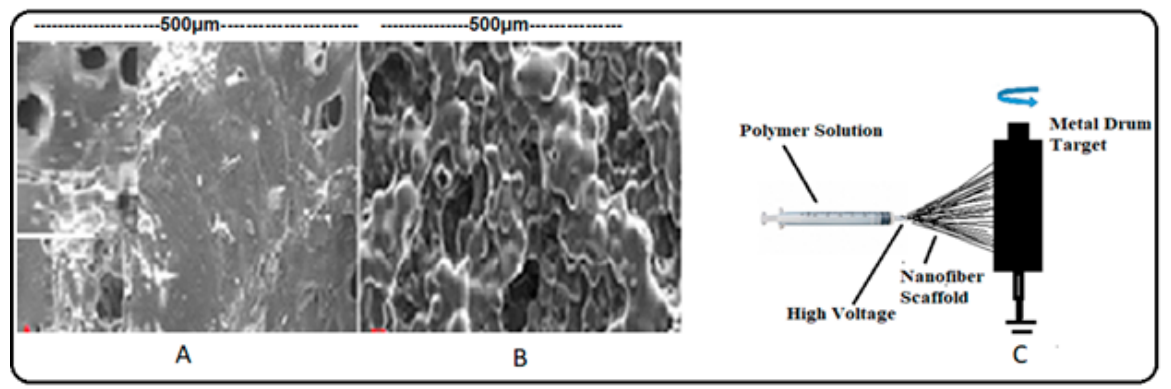

Figure 4. 3-D scaffolds. (A) Pores in the PLGA scaffold generated using the gas foaming method; (B) Pores in the PLGA scaffold generated using solvent casting and particulate leaching method; (C) Schematic of electrospinning of desired polymer solution and deposition of solid fibers on the target collector. The liquid polymer transforms into solid fibers because of the effect of high voltage [73,74].

While Tables 1-3 provide summaries of fabrication strategies for BM and cancer environment-mimicking 3-D systems, there are also major requirements for the characteristics of the scaffolds, such as mechanical strength, degradation kinetics, swelling in liquid media, and molecular linkers essential for fabrication of structural and functional stability of the scaffolds. Similarly, the HC microenvironment can be created using biomimetic synthetic polymer scaffolds, extracellular matrices (ECM), endothelial cells, and stromal cells.

Table 3. Pore sizes generated using various processes for different scaffolds.

\begin{tabular}{cccc}
\hline Process & Polymer & Pore Size $(\mu \mathrm{m})$ & References \\
\hline Conventional gas foaming & PEGDA & $100-400$ & {$[61,62]$} \\
\hline $\mathrm{CO}_{2}$-water emulsion templating & Dextran & $6.25-7$ & {$[63]$} \\
\hline Dense gas $\mathrm{CO}_{2}+$ cross-linker & Elastin & 80 & {$[64]$} \\
\hline Dense gas $\mathrm{CO}_{2}+$ cross-linker & Gelatin & $80-120$ & {$[75]$} \\
\hline Porogen leaching & PEG/PCL & $180-400$ & {$[65]$} \\
\hline Porogen leaching & PLGA & $250-500$ & {$[6]$} \\
\hline Freeze-drying & Collagen/Chitosan & 50 & {$[66]$} \\
\hline Freeze-drying & Agarose & $71-187$ & {$[67]$} \\
\hline Freeze-drying & Chitosan, alginate & $60-150$ & {$[68]$} \\
\hline Freeze-drying & Gelatin & $40-500$ & {$[69]$} \\
\hline Freeze-drying & PVA/PCL & $30-300$ & {$[70]$} \\
\hline Freeze-drying & Chitosan/PCL & $10-100$ & {$[72]$} \\
\hline Electrospinning & Gelatin/PCL & $20-80$ & {$[72,74]$} \\
\hline
\end{tabular}

\subsection{Mechanical Sterngth and Stiffness Characterization of Bone Marrow}

The mechanical properties of BM niches are varied [76] with a higher value of $435 \mathrm{kPa}$ in endosteum [77], 2-10 $\mathrm{kPa}$ in marrow sinusoids [78,79], and $0.3 \mathrm{kPa}$ in the central marrow [80]. Hydroxyapatite (HA) having higher elastic modules when fabricated with collagen forms an ECM-like scaffold mimicking the central marrow environment. The mechanical strength of the scaffold, apart from the surface chemistry and topographical features, affects MSC growth, differentiation, and regenerative capacity in the 3-D cultures [81-84]. The mineralization of BM causes enhanced stiffness. The HSCs grown in the matrix with mechanical strength of $3.7 \mathrm{kPa}$ remained round and wedged in the matrix, whereas in matrix scaffolds with higher mechanical strength $(>44 \mathrm{kPa})$, they are stretched and elongated, and driven to niche-mediated HSC fate decisions [85]. Human colorectal carcinoma (CRC) cell lines DLD1 and HT29 grown on 3-D laminin enriched ECM [86] and the breast cancer cell line 
MCF-7 grown in 3-D collagen scaffolds exhibited an enhanced expression of their respective cancer stem cell characteristics [87]. A variety of linkers and cross-linker molecules are used in the fabrication of scaffolds. They maintain the structural stability and strength of scaffolds when layers of different polymers are involved in the fabrication process. The biomimetic scaffolds are surface-modified and functioned with a variety of active biomolecules to mimic the BM and $\mathrm{HCs}$ environments or for any other applications. The protein chemical targets, known as primary amines $\left(-\mathrm{NH}_{2}\right)$, carboxyls $(-\mathrm{COOH})$, and sulfhydryls $(-\mathrm{SH})$ account for the vast majority of cross-linking and chemical modification methods for bioconjugation. A novel phosphoramidite (PA) linker is also reported for AFM single molecule force spectroscopy experiments [88]. The cross-linker molecules establish interconnections of various biological molecules for fabrication of bioactive scaffolds.

\subsection{Application of Biomimetic Scaffolds in Reconstion of BM and HCs Niches}

In the BM environment, various cells interact and function to maintain BM homeostasis. BM niches can be created in vitro mimicking in vivo niches. Second, HCs interact with BM to create a specific BM pathophysiological environment.

3.5.1. Co-Cultured Hematopoietic Stem Cells with Other BM Component Systems Modeling the BM Niche Compartments In Vitro with In Vivo Conditions

The co-culture system facilitates our understanding of the natural interaction between the cell types and its mechanisms. The knowledge of interactions helps in regulating growth and survival in the event of damages caused by irradiation and chemotherapy. HSCs in the BM interact with MSCs, macrophages, endothelial cells, and myeloma cells in cancer disease modeling of niche components in vitro. Co-cultures of HSCs and MSCs have been extensively studied $[14,89,90]$. Theresa Vasco's group observed that iPSC-derived MSCs are less supportive to HSC than are primary MSCs in terms of lower long-term culture-initiating cell (LTC-IC) frequency with iPSC-MSCs as compared to primary MSCs [91]. Activated BM monocytes and macrophages preserve primitive hematopoietic cells in the bone marrow [92]. Jana Travnickova's group demonstrated the control of HSPC mobilization and definitive hematopoiesis by macrophages [93]. The transfer of MSC-secreted ECM to MSC cultures promoted osteogenesis and bone formation in an ectopic rat model [35-37,94-96]. For in vitro 3-D model of BM tissue engineering, we used cKit enriched BM derived HSCs and demonstrated the formation of spheroids. As shown in Figure 5A,B, BM-HSC grew on PLGA and hydroxyapatite (HA) composite 3-D scaffold, forming stem cell spheroids. We co-cultured MSC and HUVEC on PLGA-HA and Matrigel composite scaffolds as a BM niche and demonstrated the formation of microvessels (MVs), as shown in Figure 5C-E.

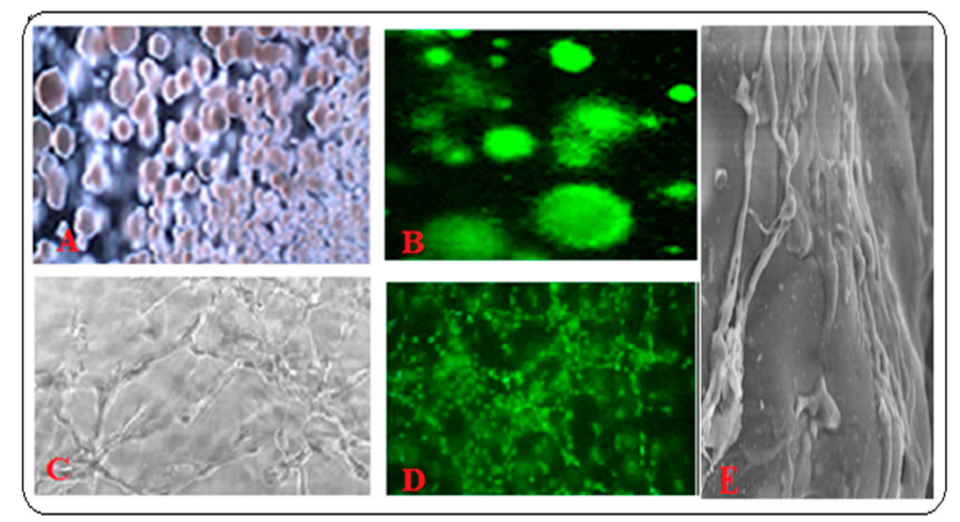

Figure 5. HSC from BM grown on PLGA-hydroxyapatite (HA) scaffold: (A) Bright field image of the spheroid colonies; (B) Fluorescent image after staining the colonies with acridine orange-ethidium bromide stains; (C,D) 3-D BM- MSCs and HUVEC co-cultures on PLGA-HA and Matrigel scaffold, (E)- SEM image of MVs. All other microscope images were taken using $5 \times$ objective. 
3.5.2. Biomimetic Scaffold Implantation, Not as a Prosthesis, for Desired BM Tissue Repair and Development

In tissue engineering, culture-expanded cells and scaffolds are used to produce a tissue construct for implantation. They support tissue regeneration and growth, but not as a prosthesis. In bone disorders, because of disease, irradiation, and chemotherapy, the bone environment is damaged. As a repairing strategy, scaffolds were seeded with MSCs, embryonic stem cells (ESCs), adult stem cells, induced pluripotent stem cells (iPSCs), and platelet-rich plasma (PRP) for recovering and repairing the damaged bone tissue [97]. Similarly, damaged central marrow and perivascular regions can be repaired using soft hydrogel-based scaffolds. MSCs grown on polycaprolactone (PCL) fibrous scaffolds produced paracrine products involved in tissue repair/regeneration [73]. An advanced method of biomimetic engineered bone marrow (eBM) is a "bone marrow-on-a-chip" microfluidic system. It involves culturing the cells on a scaffold in vitro, implantation in vivo, removal, and perfusion with media in microfluidic devices. It was demonstrated to have HSC and progenitor cell characteristics $[40,98]$. The MSC and cord blood derived HSPC cultured on hydroxyapatite coated zirconium oxide scaffold showed that HSPC remained in their primitive state $\left(\mathrm{CD} 34^{+} \mathrm{CD} 38^{-}\right)$and were capable of forming all major colonies [53].

\subsubsection{Scaffold for Studying Hematological Cancers}

With the advent of 3-D culture systems, malignancies, predominantly cancer cells from solid tumors such as breast cancer were utilized to understand the role of the cancer environment and cancer progression. Breast cancer cells grown in the cancer environment mimicking 3-D cultures using PLGA and PCL scaffolds showed comparative biomarker expression as observed in vivo [99]. It indicates the usefulness of scaffolds in cancer research in understanding cancer biology, anti-cancer drug screening, and control of cancer progression. Mouse CT26 colon cancer cells and BM-derived dendritic cells (BM-DC) co-cultures on an electrospun fibrous scaffold increased expression of CD86 and major histocompatibility complex Class II [100]. 3-D anisotropic collagen scaffolds were used for breast cancer cell migration studies, and showed increased migration potentials in the cancer mimicking 3-D cultures [101]. These studies indicate the substantial potential for the design and fabrication of composite scaffolds for mimicking the cancer tumor environment.

\subsubsection{Interaction between Hematological Cancer and Bone Marrow Niche}

The HSCs reside in BM microenvironment niches that can regulate their self-renewal and differentiation. Similarly, hematological cancer stem cells (HCSCs) reside in the cancer niche, and microenvironmental cues regulate their growth and proliferation during tumor progression and development [102]. In the BM niche, MSCs interact with cancer cells, promote tumor progression and modulate the extracellular matrix (ECM) environment such that it is favorable for the invading tumor cells $[103,104]$. With the increasing rate of BM disorders and conditions, as well as the use of therapeutic radiation on the $\mathrm{BM}$, engineered $\mathrm{BM}$ is considered as a potential alternative source for $\mathrm{BM}$ restoration. The disturbance in hematopoietic homeostasis leads to hematological cancers (HCs)/hematological malignancies and leukemic stem cell (LSC) formation. LSC/leukemia pathophysiology depends on biological cues from the BM niche for survival and proliferation. Upon administration of chemotherapeutics, LSC/leukemia cells use the BM niche as a sanctuary for survival and to escape from the therapeutic agents, acquiring chemoresistance [102,105-110]. A few recent publications are available concerning the study of hematological malignancies and their physiopathology in an ex vivo disease environment mimicking a 3-D scaffold system. The 3-D and microfluidic platform scaffolds were used to mimic the AML niche and demonstrated retention of the cells' phenotype and proliferation, compared to the 2-D cultures [111]. Polyurethane (PU)-collagen scaffolds were used to study the biology and treatment of primary AML in an ex vivo condition [112]. Different leukemia cell lines cultured on a 3-D stromal-based model were shown to be more resistant to drug-induced apoptosis compared to effects in 2-D cultures. Similarly, N-cadherin expression in treated 3-D cultures, as compared to 2-D 
cultures, is indicative of cell proliferation and chemotherapy resistance [56]. Leukemia cells flourish in the BM microenvironment and may be resistant to cytotoxic drugs. Disrupting the interaction of leukemia cells and stromal cells in biomimetic polystyrene 3-scaffolds impairs their ability to gain resistance and enhances the killing effect of chemotherapy drugs [57]. Thus, BM mimetic 3-D scaffolds help in understanding the drug efficacy and toxicity studies in vitro with in vivo conditions. A poly (ethylene glycol) (starPEG)-heparin hydrogel scaffold was used to grow leukemia lines, KG1a, MOLM13, MV4-11, and OCI-AML3, and primary cells from AMLs, HUVCEs, and MSC to mimic cell interactions between AML and the vascular niche [58]. This approach is facilitating visualization of AML-vascular interactions in chemotherapeutic responses. 3-D scaffolds were used for demonstrating a mesenchymal stem cell model of the multiple myeloma (MM) bone marrow niche, indicating cytokine secretion by MSC in 3-D cultures support MM cell growth [97]. Further, they have demonstrated MSC with conserved phenotype (CD73 + CD90 + CD105+), activation of osteogenesis (MMP13, SPP1, ADAMTS4, and MGP genes), and osteoblastogenic differentiation. MSCs were grown on silk fibrous 3-D scaffolds in dexamethasone-free osteogenic media and demonstrated osteogenesis in a multiple myeloma-mimicking BM environment [59]. HSC niche mimetic 3-D scaffolds in combination with perfusion in static and dynamic cultures demonstrated the role of cytokines dose and application in vitro model for testing myeloid toxicity [55]. Further, they have demonstrated the effect of dimensionality (2-D or 3-D) and mode (static or dynamic) of HSPC/MSC co-cultures to assess myelotoxicity to 5-fluorouracil. The advanced 3-D cultured organoids are self-organized tissue architecture. They are grown from pluripotent ESCs, iPSCs, and adult stem cells [113]. They recapitulate the developmental events of tissues and organs, including natural orientation and spatial organization of different tissue specific cell types, cell-cell interactions, cell-matrix interactions, and response to biophysical cues, and more representative of vivo physiology [114]. The organoids of cancer were developed from primary colon, esophagus, pancreas, stomach, liver endometrium and emphasized the importance of organoids in cancer research [115]. The organoids grown from adult stem cells are suitable for in vitro and in vivo modeling, drug therapy, and regenerative therapy $[113,116]$.

\subsection{Choice of Materials and Advanced Fabrication Technologies for Scaffold Preparation}

The fabrication of efficient and BM and HCs mimetic 3-D scaffolds needs to be improved with more accurate representation of the components found in the natural BM and HCs as depicted in Table 1. The basic requirements for the scaffold materials are biocompatibility, biodegradability, suitable mechanical properties, scaffold architecture, and fabrication technologies. All of these characteristics are assessed before fabricating a scaffold. Osteoconductive and time-frame biodegradability of scaffolds are critical for osteoblastic differentiation, bone regeneration, and vascularization $[117,118]$. The mechanical properties (Mpa) and Young's modulus of ECM-like polymer scaffolds fabricated for various tissue engineering applications were studied [119-123]. The scaffold fabrication for mimicking the endosteum region needs HA with PCL in preference over a PLGA polymer because of the long degradation time for PCL, ranging from 1-2 years compared to PGA scaffolds [124].

Currently, the scaffold is prepared predominantly by manual methods. There are challenges to prepare this scaffold readily without in-depth experience. Recently introduced scaffold printing and bioprinting technologies are in the market for printing architectural and compositional elements of desired 3-D scaffolds and target tissue formations. Efforts have been made to improve accuracy, quality and reproducibility of design using computer-aided design (CAD) and fabrication of functionally graded scaffolds. In 3-D tissue printing, the target tissue elements are mixed with ECM like polymer scaffolds and printed in precise geometrical tissue or organ structures. The steps involve in selecting the organ of interest to be printed; scanning (X-ray, MRI or CT scan); creating graphics (Bio-CAD or Med-CAD); use of Rhinos software for modelling geometry and printing with cell types from the organ of interest [125]. Bioreactors with controlled in vivo conditions help the tissue in proper circulation of oxygen, nutrients, catabolic and anabolic waste material from the tissue. Thus, bioreactors mitigate the drawbacks of 3-D scaffold-based cell culture systems, predominantly by manual methods. 
In magnetic levitation, the cells form a micro tissue rather than individual cells in the media and air interface. The micro tissue of BM-MSC formed under the magnetic field prevent spontaneous differentiation into other cell phenotypes, and retaining high expression of stem cell markers STRO- 1 and nestin up to 14 days, unlike in 2-D monolayer cultures where MSC stem cell markers were lost within 3 days [126]. Magnetic levitated breast cancer (BC) and colorectal cancer (CRC) cells expressed high levels of $\mathrm{N}$-cadherin and epidermal growth factor receptor molecules comparable to $\mathrm{BC}$ and CRC xenografts grown in severe combined immunodeficient (SCID) mice [127]. Magnetic levitated 3-D cancer cells/micro tissue was used as in vitro model for in vitro tumor development and tumor suppression therapeutics, instead of use of mice [127]. Although it is not truly representative of BM and cancer environment niches, it facilitates cell-cell interactions and aggregate growth that leads to the formation of BM and HC micro-tissue in vitro 3-D models with in vivo conditions for testing drug efficacy and toxicity. Thermoreversible injectable hydrogel-based materials are widely used for in neuro-engineering applications $[74,128]$.

\subsection{Future Perspectives and Conclusion}

Most of the research on cancer was focused on solid cancer tumors, as such now there is a greater opportunity to focus on HCs. The potential of MSC to increase proliferation and maintenance of hematopoietic progenitor cells is harnessed in co-cultures with the HSC to enhanced engraftment of HSC in transplantation [13], formation of micro blood vessels with endothelial cells [44], multi-lineage hematopoiesis in co-cultures with differentiated osteoblasts [90] can be further exploited in 3-D co-cultures modeling the niche components in vitro using advanced scaffold systems. The role of macrophages in maintaining hematopoiesis $[16,17]$ can be further assessed. HSC niche mimetic 3-D scaffolds may be used to study the role of cytokines and application in an in vitro model for testing myeloid toxicity. As $\mathrm{HC}$ cells flourish in the BM microenvironment and are resistant to cytotoxic drugs, $\mathrm{BM}$ and HC mimetic 3-D scaffolds help in understanding the drug efficacy and toxicity studies in vitro with in vivo conditions. The study of primary cells from AML, HUVCE and MSC to mimic cell interactions between AML and the vascular niche assists in visualization of AML-vascular interactions in chemotherapeutic responses. The MSC model of the multiple myeloma (MM) BM niche indicates cytokine secretion by MSC in 3-D cultures supporting MM cell growth. The various scaffold types used for different applications in BMTE and HCTE are summarized in Figure 6.

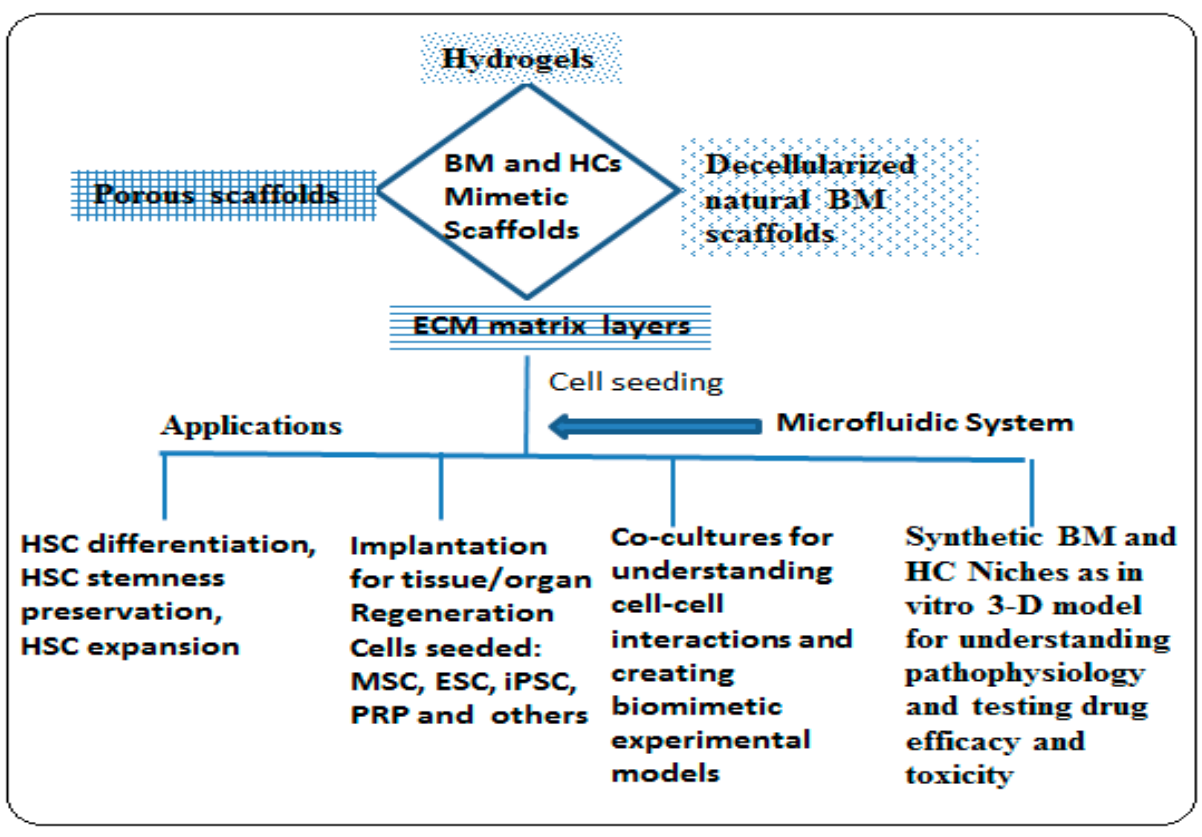

Figure 6. Schematic of applications of various types of scaffolds in BMTE and HCTE. 
In view of the clinical importance of therapeutic regeneration and restoration of BM tissue after damage caused by chemo- and radiation therapy and understanding the pathophysiology of HC in $\mathrm{BM}$ niches perspectives and development of novel therapeutics, attention has focused on improving BM and HC mimetic 3-D scaffolds. The other technologies such as CFUs, PDMS based microfluidic systems, organ-on-chip [129,130], bone marrow-on-a-chip [110], induced pluripotent stem cells (iPSC) [131] long-term culture of human hematopoietic stem cells in a 3-D microfluidic environment $[53,132]$ for studying specific BM niche conditions and replicating BM physiology in vitro need to be improved. Further advances in 3-D non-destructive, non-invasive tissue analysis methods help in adopting 3-D culture systems widely [60,133-138]. As the BM environment is heterogeneous in nature, a composite cell culture system with multiple cell types and advanced scaffold architecture materials are needed to replicate the various microenvironment niches and large-scale ex vivo expansion of HSC and MSC for transplantation and therapy.

The combination therapy of chemo and radiation in BM and HCs mimetic 3-D scaffolds and the scaffold-free magnetic levitation systems will open new frontiers of BM and HCs therapeutics in vitro with in vivo conditions. Biomimetic BM phantoms are used in this study for the first time as an in vitro model to study the radiation effects on hematological cancers. BM phantoms will revolutionize not only in vitro studies of hematological cancers but also radiofrequency (RF) heating and thermal monitoring studies.

Currently, such data are scanty or lacking and efforts are needed in this direction for BM phantoms and printing 3-D scaffolds and 3-D tissue.

Author Contributions: D.J. and S.K.H. reviewed articles and wrote the manuscript. All authors have read and agreed to the published version of the manuscript.

Funding: This study was supported by grants by the NIH National Institutes of Health grant (2R01CA154491) (SH), and (P30CA033572) City of Hope Cancer Center. The authors thank James Sanchez and Biswajoy Ghosh for reviewing and providing input to improve the manuscript. The content is solely the responsibility of the authors and does not necessarily represent the official views of the NIH.

Conflicts of Interest: The authors declare no conflict of interest.

\section{Abbreviations}

$\begin{array}{llll}\text { ALL } & \text { Acute lymphoid leukemia } & \text { HSPC } & \text { Hematopoietic stem and progenitor cells } \\ \text { AML } & \text { Acute myeloid leukemia } & \text { HUVEC } & \text { Human umbilical vein endothelial cell } \\ \text { BC } & \text { Breast cancer } & \text { LN } & \text { Laminin } \\ \text { BLC } & \text { Bone lining cells } & \text { LTC-IC } & \text { long-term culture-initiating cell } \\ \text { BM } & \text { Bone marrow } & \text { MSC } & \text { Mesenchymal stem cell } \\ \text { BMTE } & \text { Bone and marrow tissue engineering } & \text { MVs } & \text { Microvessels } \\ \text { CAR } & \text { CXCL12-abundant reticular } & \text { NP } & \text { Nanoparticle } \\ \text { CFU } & \text { Colony forming unit } & \text { PCL } & \text { Polycaprolactone } \\ \text { CLL } & \text { Chronic lymphoid leukemia } & \text { PDMS } & \text { Polydimethylsiloxane } \\ \text { CML } & \text { Chronic myeloid leukemia } & \text { PEG } & \text { Polyethylene glycol } \\ \text { COL } & \text { Collagen } & \text { PEGDA } & \text { Polyethylene (glycol) Diacrylate } \\ \text { CRC } & \text { Colorectal cancer } & \text { PLA } & \text { Poly-L-lactic acid } \\ \text { CS } & \text { Chitosan } & \text { PLAGA } & \text { Poly (lactic acid -co-glycolic acid) } \\ \text { EBM } & \text { Engineered bone marrow } & \text { PLGA } & \text { Poly(lactide-co-glycolide) copolymer } \\ \text { ECM } & \text { Extracellular matrix } & \text { PRP } & \text { Platelet rich plasma } \\ \text { ESC } & \text { Embryonic stem cell } & \text { PVA } & \text { Polyvinyl alcohol } \\ \text { FN } & \text { Fibronectin } & \text { ROS } & \text { Reactive oxygen species } \\ \text { GAG } & \text { Glycosaminoglycan } & \text { SEM } & \text { Scanning electron microscope } \\ \text { HA } & \text { Hydroxyapatite } & \text { SCF } & \text { Stem cell factor } \\ \text { HCs } & \text { Hematological cancers } & \text { SDF1 } & \text { Stromal derived factor 1 } \\ \text { HCTE } & \text { Hematological cancer tissue engineering } & \text { TCPS } & \text { Tissue culture polystyrene } \\ \text { hiPSC } & \text { Human induced pluripotent stem cell } & \text { TE } & \text { Tissue engineering } \\ \text { HPC } & \text { Hematopoietic progenitor cell } & \text { TEB } & \text { Tissue engineered bone } \\ \text { HSC } & \text { Hematopoietic stem cell } & & \\ & & & \end{array}$




\section{References}

1. Day, C.P.; Carter, J.; Bonomi, C.; Hollingshead, M.; Merlino, G. Preclinical therapeutic response of residual metastatic disease is distinct from its primary tumor of origin. Int. J. Cancer 2012, 130, 190-199. [CrossRef] [PubMed]

2. Voskoglou-Nomikos, T.; Pater, J.L.; Seymour, L. Clinical predictive value of the in vitro cell line, human xenograft, and mouse allograft preclinical cancer models. Clin. Cancer Res. 2003, 9, 4227-4239. [PubMed]

3. Asghar., W.; El Assal, R.; Shafiee, H.; Pitteri, S.; Paulmurugan, R.; Demirci, U. Engineering cancer microenvironments for in vitro 3-D tumor models. Mater. Today 2015, 18, 539-553. [CrossRef] [PubMed]

4. Gamba, L.; Harrison, M.; Lien, C.-L. Cardiac regeneration in model organisms. Curr. Treat. Options Cardiovasc. Med. 2014, 16, 288. [CrossRef]

5. Tanaka, H.V.; Ng, N.C.Y.; Yu, Z.Y.; Casco-Robles, M.M.; Maruo, F.; Tsonis, P.A.; Chiba, C. A developmentally regulated switch from stem cells to dedifferentiation for limb muscle regeneration in newts. Nat. Commun. 2016, 7, 11069. [CrossRef]

6. Dadsetan, M.; Hefferan, T.E.; Szatkowski, J.P.; Mishra, P.K.; Macura, S.I.; Lu, L.; Yaszemski, M.J. Effect of hydrogel porosity on marrow stromal cell phenotypic expression. Biomaterials 2008, 29, 2193-2202. [CrossRef]

7. Musey, P.I. Dasharatham Janagama and Niranjan K Talukdar. Immunodetection of vascular cells cultured on porus biodegradable scaffolds. Int. J. Cardiovasc. Med. Med. Sci. 2005, 5, $29-32$.

8. Rho, J.-Y.; Kuhn-Spearing, L.; Zioupos, P. Mechanical properties and the hierarchical structure of bone. Med. Eng. Phys. 1998, 20, 92-102. [CrossRef]

9. Wu, S.; Liu, X.; Yeung, K.W.; Liu, C.; Yang, X. Biomimetic porous scaffolds for bone tissue engineering. Mater. Sci. Eng. R Rep. 2014, 80,1-36. [CrossRef]

10. Benders, K.E.; van Weeren, P.R.; Badylak, S.F.; Saris, D.B.; Dhert, W.J.; Malda, J. Extracellular matrix scaffolds for cartilage and bone regeneration. Trends Biotechnol. 2013, 31, 169-176. [CrossRef]

11. Shekaran, A.; Garcia, A.J. Extracellular matrix-mimetic adhesive biomaterials for bone repair. J. Biomed. Mater. Res. Part A 2011, 96, 261-272. [CrossRef] [PubMed]

12. Oh, M.; Nör, J.E. The perivascular niche and self-renewal of stem cells. Front. Physiol. 2015, 6, 367. [CrossRef] [PubMed]

13. Fernández-García, M.; Yañez, R.M.; Sánchez-Domínguez, R.; Hernando-Rodriguez, M.; Peces-Barba, M.; Herrera, G.; O'Connor, J.E.; Segovia, J.C.; Bueren, J.A.; Lamana, M.L. Mesenchymal stromal cells enhance the engraftment of hematopoietic stem cells in an autologous mouse transplantation model. Stem Cell Res. Ther. 2015, 6, 165. [CrossRef] [PubMed]

14. Saleh, M. The impact of mesenchymal stem cells on differentiation of hematopoietic stem cells. Adv. Pharm. Bull. 2015, 5, 299. [CrossRef]

15. Boulai, P.E.; Frenette, P.S. Making sense of hematopoietic stem cell niches. Blood 2015, 125, $2621-2629$. [CrossRef]

16. Winkler, I.G.; Sims, N.A.; Pettit, A.R.; Barbier, V.; Nowlan, B.; Helwani, F.; Poulton, I.J.; van Rooijen, N.; Alexander, K.A.; Raggatt, L.J.; et al. Bone marrow macrophages maintain hematopoietic stem cell (HSC) niches and their depletion mobilizes HSCs. Blood 2010, 116, 4815-4828. [CrossRef]

17. Chow, A.; Lucas, D.; Hidalgo, A.; Méndez-Ferrer, S.; Hashimoto, D.; Scheiermann, C.; Battista, M.; Leboeuf, M.; Prophete, C.; van Rooijen, N. Bone marrow CD169+ macrophages promote the retention of hematopoietic stem and progenitor cells in the mesenchymal stem cell niche. J. Exp. Med. 2011, 208, 261-271. [CrossRef]

18. Ratajczak, M.Z.; Suszynska, M. Emerging strategies to enhance homing and engraftment of hematopoietic stem cells. Stem Cell Rev. Rep. 2016, 12, 121-128. [CrossRef]

19. Wysoczynski, M.; Reca, R.; Ratajczak, J.; Kucia, M.; Shirvaikar, N.; Honczarenko, M.; Mills, M.; Wanzeck, J.; Janowska-Wieczorek, A.; Ratajczak, M.Z. Incorporation of CXCR4 into membrane lipid rafts primes homing-related responses of hematopoietic stem/progenitor cells to an SDF-1 gradient. Blood 2005, 105, 40-48. [CrossRef]

20. Ditadi, A.; Sturgeon, C.M.; Keller, G. A view of human haematopoietic development from the Petri dish. Nat. Rev. Mol. Cell Biol. 2017, 18, 56. [CrossRef]

21. Islam, M.S.; Stemig, M.E.; Takahashi, Y.; Hui, S.K. Radiation response of mesenchymal stem cells derived from bone marrow and human pluripotent stem cells. J. Radiat. Res. 2014, 56, 269-277. [CrossRef] [PubMed] 
22. Chen, M.-F.; Lin, C.-T.; Chen, W.-C.; Yang, C.-T.; Chen, C.-C.; Liao, S.-K.; Liu, J.M.; Lu, C.-H.; Lee, K.-D. The sensitivity of human mesenchymal stem cells to ionizing radiation. Int. J. Radiat. Oncol. Biol. Phys. 2006, 66, 244-253. [CrossRef] [PubMed]

23. Nicolay, N.H.; Perez, R.L.; Saffrich, R.; Huber, P.E. Radio-resistant mesenchymal stem cells: Mechanisms of resistance and potential implications for the clinic. Oncotarget 2015, 6, 19366-19380. [CrossRef] [PubMed]

24. Bandyopadhyay-Ghosh, S. Bone as a collagen-hydroxyapatite composite and its repair. Trends Biomater. Artif. Organs 2008, 22, 116-124.

25. Martin, R. (Ed.) Bone as a Ceramic Composite Material. In Materials Science Forum; Trans. Tech. Publ.: Kapellweg, Switzerland, 1999.

26. Wahl, D.A.; Czernuszka, J.T. Collagen-Hydroxyapatite Composites for Hard Tissue Repair. Eur. Cells Mater. 2006, 11, 43-56. [CrossRef]

27. Hench, L.L.; Jones, J.R. Biomaterials, Artificial Organs and Tissue Engineering; Elsevier: Amsterdam, The Netherlands, 2005.

28. Sheikh, Z.; Najeeb, S.; Khurshid, Z.; Verma, V.; Rashid, H.; Glogauer, M. Biodegradable Materials for Bone Repair and Tissue Engineering Applications. Materials 2015, 8, 5744-5794. [CrossRef]

29. Martinez, C.; Gilabert, U.; Garrido, L.; Rosenbusch, M.; Ozols, A. Functionalization of Hydroxyapatite Scaffolds with ZnO. Procedia Mater. Sci. 2015, 9, 484-490. [CrossRef]

30. Ronen, A.; Semiat, R.; Dosoretz, C. Antibacterial Efficiency of a Composite Spacer Containing Zinc Oxide Nanoparticles. Procedia Eng. 2012, 44, 581-582. [CrossRef]

31. Jugdaohsingh, R. Silicon and bone health. J. Nutr. Health Aging 2007, 11, 99-110.

32. Annabi, N.; Nichol, J.W.; Zhong, X.; Ji, C.; Koshy, S.T.; Khademhosseini, A.; Dehghani, F. Controlling the Porosity and Microarchitecture of Hydrogels for Tissue Engineering. Tissue Eng. Part B Rev. 2010, 16, 371-383. [CrossRef]

33. Kuboki, Y.; Takita, H.; Kobayashi, D.; Tsuruga, E.; Inoue, M.; Murata, M.; Nagai, N.; Dohi, Y.; Ohgushi, H. BMP-induced osteogenesis on the surface of hydroxyapatite with geometrically feasible and nonfeasible structures: Topology of osteogenesis. J. Biomed. Mater. Res. Part A 1998, 39, 190-199. [CrossRef]

34. Karageorgiou, V.; Kaplan, D. Porosity of 3D biomaterial scaffolds and osteogenesis. Biomaterials 2005, 26, 5474-5491. [CrossRef] [PubMed]

35. Decaris, M.L.; Leach, J.K. Design of Experiments Approach to Engineer Cell-Secreted Matrices for Directing Osteogenic Differentiation. Ann. Biomed. Eng. 2010, 39, 1174-1185. [CrossRef] [PubMed]

36. Decaris, M.L.; Binder, B.Y.; Soicher, M.A.; Bhat, A.; Leach, J.K. Cell-Derived Matrix Coatings for Polymeric Scaffolds. Tissue Eng. Part A 2012, 18, 2148-2157. [CrossRef] [PubMed]

37. Decaris, M.L.; Mojadedi, A.; Bhat, A.; Leach, J.K. Transferable cell-secreted extracellular matrices enhance osteogenic differentiation. Acta Biomater. 2012, 8, 744-752. [CrossRef]

38. Martini, F.; Nath, J.; Bartholomew, E. Development and inheritance. Fundam. Anat. Physiol. 2004, $20,1123$.

39. Mendelson, A.; Frenette, P.S. Hematopoietic stem cell niche maintenance during homeostasis and regeneration. Nat. Med. 2014, 20, 833-846. [CrossRef]

40. Papadimitropoulos, A.; Piccinini, E.; Brachat, S.; Braccini, A.; Wendt, D.; Barbero, A.; Jacobi, C.; Martin, I. Expansion of Human Mesenchymal Stromal Cells from Fresh Bone Marrow in a 3D Scaffold-Based System under Direct Perfusion. PLoS ONE 2014, 9, e102359. [CrossRef]

41. Walenda, T.; Bork, S.; Horn, P.; Wein, F.; Saffrich, R.; Diehlmann, A.; Eckstein, V.; Ho, A.D.; Wagner, W. Co-culture with mesenchymal stromal cells increases proliferation and maintenance of haematopoietic progenitor cells. J. Cell. Mol. Med. 2009, 14, 337-350. [CrossRef]

42. Brennan, M.A.; Davaine, J.-M.; Layrolle, P. Pre-vascularization of bone tissue-engineered constructs. Stem Cell Res. Ther. 2013, 4, 96. [CrossRef]

43. Itkin, T.; Gur-Cohen, S.; Spencer, J.A.; Schajnovitz, A.; Ramasamy, S.K.; Kusumbe, A.P.; Ledergor, G.; Jung, Y.; Milo, I.; Poulos, M.G.; et al. Distinct bone marrow blood vessels differentially regulate haematopoiesis. Nat. Cell Biol. 2016, 532, 323-328. [CrossRef] [PubMed]

44. Saleh, A.F.; Whyte, M.; Genever, P.G. Effects of endothelial cells on human mesenchymal stem cell activity in a three-dimensional in vitro model. Eur. Cells Mater. 2011, 22, 242-257. [CrossRef] [PubMed]

45. Sivaraj, K.K.; Adams, R.H. Blood vessel formation and function in bone. Development 2016, 143, $2706-2715$. [CrossRef] [PubMed] 
46. Jeon, O.H.; Panicker, L.M.; Lu, Q.; Chae, J.J.; Feldman, R.A.; Elisseeff, J.H. Human iPSC-derived osteoblasts and osteoclasts together promote bone regeneration in 3D biomaterials. Sci. Rep. 2016, 6, 26761. [CrossRef]

47. Kelly, B.; O’Neill, L.A.J. Metabolic reprogramming in macrophages and dendritic cells in innate immunity. Cell Res. 2015, 25, 771-784. [CrossRef]

48. Yamazaki, S.; Ema, H.; Karlsson, G.; Yamaguchi, T.; Miyoshi, H.; Shioda, S.; Taketo, M.M.; Karlsson, S.; Iwama, A.; Nakauchi, H. Nonmyelinating Schwann Cells Maintain Hematopoietic Stem Cell Hibernation in the Bone Marrow Niche. Cell 2011, 147, 1146-1158. [CrossRef]

49. Lucas, D.; Scheiermann, C.; Chow, A.; Kunisaki, Y.; Bruns, I.; Barrick, C.A.; Tessarollo, L.; Frenette, P.S. Chemotherapy-induced bone marrow nerve injury impairs hematopoietic regeneration. Nat. Med. 2013, 19, 695-703. [CrossRef]

50. Tuljapurkar, S.R.; McGuire, T.R.; Brusnahan, S.K.; Jackson, J.D.; Garvin, K.L.; Kessinger, M.A.; Lane, J.T.; Kane, B.J.O.; Sharp, J.G. Changes in human bone marrow fat content associated with changes in hematopoietic stem cell numbers and cytokine levels with aging. J. Anat. 2011, 219, 574-581. [CrossRef]

51. Signer, R.A.; Morrison, S.J. Mechanisms that Regulate Stem Cell Aging and Life Span. Cell Stem Cell 2013, 12, 152-165. [CrossRef]

52. Suda, T.; Takubo, K.; Semenza, G.L. Metabolic Regulation of Hematopoietic Stem Cells in the Hypoxic Niche. Cell Stem Cell 2011, 9, 298-310. [CrossRef]

53. Sieber, S.; Wirth, L.; Cavak, N.; Koenigsmark, M.; Marx, U.; Lauster, R.; Rosowski, M. Bone marrow-on-a-chip: Long-term culture of human haematopoietic stem cells in a three-dimensional microfluidic environment. J. Tissue Eng. Regen. Med. 2018, 12, 479-489. [CrossRef] [PubMed]

54. Nelson, M.R.; Roy, K. Bone-marrow mimicking biomaterial niches for studying hematopoietic stem and progenitor cells. J. Mater. Chem. B 2016, 4, 3490-3503. [CrossRef] [PubMed]

55. Rödling, L.; Schwedhelm, I.; Kraus, S.; Bieback, K.; Hansmann, J.; Lee-Thedieck, C. 3D models of the hematopoietic stem cell niche under steady-state and active conditions. Sci. Rep. 2017, 7, 4625. [CrossRef] [PubMed]

56. Aljitawi, O.S.; Li, D.; Xiao, Y.; Zhang, D.; Ramachandran, K.; Stehno-Bittel, L.; Van Veldhuizen, P.; Lin, T.L.; Kambhampati, S.; Garimella, R. A novel three-dimensional stromal-based model for in vitro chemotherapy sensitivity testing of leukemia cells. Leuk. Lymphoma 2014, 55, 378-391. [CrossRef]

57. Shen, Z.-H.; Zeng, D.-F.; Wang, X.-Y.; Ma, Y.-Y.; Zhang, X.; Kong, P.-Y. Targeting of the leukemia microenvironment by $\mathrm{c}(\mathrm{RGDfV})$ overcomes the resistance to chemotherapy in acute myeloid leukemia in biomimetic polystyrene scaffolds. Oncol. Lett. 2016, 12, 3278-3284. [CrossRef]

58. Bray, L.J.; Binner, M.; Körner, Y.; Von Bonin, M.; Bornhäuser, M.; Werner, C. A three-dimensional ex vivo tri-culture model mimics cell-cell interactions between acute myeloid leukemia and the vascular niche. Haematologica 2017, 102, 1215-1226. [CrossRef]

59. Reagan, M.R.; Mishima, Y.; Glavey, S.V.; Zhang, Y.; Manier, S.; Lu, Z.N.; Memarzadeh, M.; Zhang, Y.; Sacco, A.; Aljawai, Y.; et al. Investigating osteogenic differentiation in multiple myeloma using a novel 3D bone marrow niche model. Blood 2014, 124, 3250-3259. [CrossRef]

60. Whang, K.; Healy, K.E.; Elenz, D.R.; Nam, E.K.; Tsai, D.C.; Thomas, C.H.; Nuber, G.W.; Glorieux, F.H.; Travers, R.; Sprague, S.M. Engineering Bone Regeneration with Bioabsorbable Scaffolds with Novel Microarchitecture. Tissue Eng. 1999, 5, 35-51. [CrossRef]

61. Janagama, D.G.; Basson, M.D.; Bumpers, H.L. Abstract 2026: Targeted delivery of therapeutic NefM1 peptide with single-walled carbon nanotubes (SWNTs) suppresses growth of 3-D cultures of breast and colon cancers. Mol. Cell. Biol. 2012, 72, 2026. [CrossRef]

62. Keskar, V.; Marion, N.W.; Mao, J.J.; Gemeinhart, R.A. In VitroEvaluation of Macroporous Hydrogels to Facilitate Stem Cell Infiltration, Growth, and Mineralization. Tissue Eng. Part A 2009, 15, 1695-1707. [CrossRef]

63. Palocci, C.; Barbetta, A.; La Grotta, A.; Dentini, M. Porous Biomaterials Obtained Using Supercritical $\mathrm{CO}_{2}$-Water Emulsions. Langmuir 2007, 23, 8243-8251. [CrossRef] [PubMed]

64. Annabi, N.; Mithieux, S.M.; Boughton, E.A.; Ruys, A.J.; Weiss, A.S.; Dehghani, F. Synthesis of highly porous crosslinked elastin hydrogels and their interaction with fibroblasts in vitro. Biomaterials 2009, 30, 4550-4557. [CrossRef] [PubMed] 
65. Park, J.S.; Woo, D.G.; Sun, B.K.; Chung, H.-M.; Im, S.J.; Choi, Y.M.; Park, K.; Huh, K.M.; Park, K.-H. In vitro and in vivo test of PEG/PCL-based hydrogel scaffold for cell delivery application. J. Control. Release 2007, 124, 51-59. [CrossRef] [PubMed]

66. Wu, X.; Black, L.; Santacana-Laffitte, G.; Patrick, C.W. Preparation and assessment of glutaraldehyde-crosslinked collagen-chitosan hydrogels for adipose tissue engineering. J. Biomed. Mater. Res. Part A 2007, 81, 59-65. [CrossRef]

67. Stokols, S.; Tuszynski, M.H. The fabrication and characterization of linearly oriented nerve guidance scaffolds for spinal cord injury. Biomaterials 2004, 25, 5839-5846. [CrossRef]

68. Ho, M.-H.; Kuo, P.-Y.; Hsieh, H.-J.; Hsien, T.-Y.; Hou, L.-T.; Lai, J.-Y.; Wang, D.-M. Preparation of porous scaffolds by using freeze-extraction and freeze-gelation methods. Biomaterials 2004, 25, 129-138. [CrossRef]

69. Kang, H.-W.; Tabata, Y.; Ikada, Y. Fabrication of porous gelatin scaffolds for tissue engineering. Biomaterials 1999, 20, 1339-1344. [CrossRef]

70. Mohan, N.; Nair, P.D. Polyvinyl alcohol-poly(caprolactone) Semi IPN scaffold with implication for cartilage tissue engineering. J. Biomed. Mater. Res. Part B Appl. Biomater. 2008, 84, 584-594. [CrossRef]

71. Sarasam, A.R.; Samli, A.I.; Hess, L.; Ihnat, M.A.; Madihally, S.V. Blending Chitosan with Polycaprolactone: Porous Scaffolds and Toxicity. Macromol. Biosci. 2007, 7, 1160-1167. [CrossRef]

72. Heydarkhan-Hagvall, S.; Schenke-Layland, K.; Dhanasopon, A.P.; Rofail, F.; Smith, H.; Wu, B.M.; Shemin, R.; Beygui, R.E.; MacLellan, W.R. Three-dimensional electrospun ECM-based hybrid scaffolds for cardiovascular tissue engineering. Biomaterials 2008, 29, 2907-2914. [CrossRef]

73. Su, N.; Gao, P.-L.; Wang, K.; Wang, J.; Zhong, Y.; Luo, Y. Fibrous scaffolds potentiate the paracrine function of mesenchymal stem cells: A new dimension in cell-material interaction. Biomaterials 2017, 141, 74-85. [CrossRef] [PubMed]

74. Bellamkonda, R.V.; Kim, Y.-T.; Kumar, S.; Janagama, D.G. Nanofilament Scaffold for Tissue Regeneration. Google Patents No 8,652,215 B2, 18 February 2014.

75. Shih, H.-H.; Lee, K.-R.; Lai, H.-M.; Tsai, C.-C.; Chang, Y.-C. Method of Making Porous Biodegradable Polymers. Google Patents No 6,673,286, 26 February 2004.

76. Jansen, L.E.; Birch, N.P.; Schiffman, J.D.; Crosby, A.J.; Peyton, S.R. Mechanics of intact bone marrow. J. Mech. Behav. Biomed. Mater. 2015, 50, 299-307. [CrossRef] [PubMed]

77. Buxboim, A.; Rajagopal, K.; Brown, A.E.; Discher, D.E. How deeply cells feel: Methods for thin gels. J. Phys. Condens. Matter 2010, 22, 194116. [CrossRef] [PubMed]

78. Ohashi, T.; Ishii, Y.; Ishikawa, Y.; Matsumoto, T.; Sato, M. Experimental and numerical analyses of local mechanical properties measured by atomic force microscopy for sheared endothelial cells. Bio-Med. Mater. Eng. 2002, 12, 319-327.

79. Engler, A.J.; Richert, L.; Wong, J.Y.; Picart, C.; Discher, D.E. Surface probe measurements of the elasticity of sectioned tissue, thin gels and polyelectrolyte multilayer films: Correlations between substrate stiffness and cell adhesion. Surf. Sci. 2004, 570, 142-154. [CrossRef]

80. Shin, J.-W.; Buxboim, A.; Spinler, K.R.; Swift, J.; Christian, D.A.; Hunter, C.A.; Léon, C.; Gachet, C.; Dingal, P.D.P.; Ivanovska, I.L.; et al. Contractile Forces Sustain and Polarize Hematopoiesis from Stem and Progenitor Cells. Cell Stem Cell 2014, 14, 81-93. [CrossRef]

81. Engler, A.J.; Sen, S.; Sweeney, H.L.; Discher, D.E. Matrix Elasticity Directs Stem Cell Lineage Specification. Cell 2006, 126, 677-689. [CrossRef]

82. Curran, J.M.; Stokes, R.; Irvine, E.; Graham, D.; Amro, N.A.; Sanedrin, R.G.; Jamil, H.; Hunt, J.A. Introducing dip pen nanolithography as a tool for controlling stem cell behaviour: Unlocking the potential of the next generation of smart materials in regenerative medicine. Lab Chip 2010, 10, 1662-1670. [CrossRef]

83. Gilbert, P.M.; Havenstrite, K.L.; Magnusson, K.E.G.; Sacco, A.; Leonardi, N.A.; Kraft, P.; Nguyen, N.K.; Thrun, S.; Lutolf, M.P.; Blau, H.M. Substrate Elasticity Regulates Skeletal Muscle Stem Cell Self-Renewal in Culture. Science 2010, 329, 1078-1081. [CrossRef]

84. McMurray, R.J.; Gadegaard, N.; Tsimbouri, P.M.; Burgess, K.V.; McNamara, L.E.; Tare, R.S.; Murawski, K.; Kingham, E.; Oreffo, R.O.C.; Dalby, M.J. Nanoscale surfaces for the long-term maintenance of mesenchymal stem cell phenotype and multipotency. Nat. Mater. 2011, 10, 637-644. [CrossRef]

85. Choi, J.S.; Harley, B.A.C. Marrow-inspired matrix cues rapidly affect early fate decisions of hematopoietic stem and progenitor cells. Sci. Adv. 2017, 3, e1600455. [CrossRef] [PubMed] 
86. Stankevicius, V.; Kunigenas, L.; Stankunas, E.; Kuodyte, K.; Strainiene, E.; Cicenas, J.; Samalavičius, N.E.; Suziedelis, K. The expression of cancer stem cell markers in human colorectal carcinoma cells in a microenvironment dependent manner. Biochem. Biophys. Res. Commun. 2017, 484, 726-733. [CrossRef] [PubMed]

87. Chen, L.; Xiao, Z.; Meng, Y.; Zhao, Y.; Han, J.; Su, G.; Chen, B.; Dai, J. The enhancement of cancer stem cell properties of MCF-7 cells in 3D collagen scaffolds for modeling of cancer and anti-cancer drugs. Biomaterials 2012, 33, 1437-1444. [CrossRef] [PubMed]

88. Tong, Z.; Mikheikin, A.; Krasnoslobodtsev, A.; Lv, Z.; Lyubchenko, Y. Novel polymer linkers for single molecule AFM force spectroscopy. Methods 2013, 60, 161-168. [CrossRef] [PubMed]

89. Jing, D.; Fonseca, A.-V.; Alakel, N.; Fierro, F.A.; Muller, K.; Bornhauser, M.; Ehninger, G.; Corbeil, D.; Ordemann, R. Hematopoietic stem cells in co-culture with mesenchymal stromal cells - modeling the niche compartments in vitro. Haematologica 2010, 95, 542-550. [CrossRef] [PubMed]

90. Huang, X.; Zhu, B.; Wang, X.; Xiao, R.; Wang, C. Three-dimensional co-culture of mesenchymal stromal cells and differentiated osteoblasts on human bio-derived bone scaffolds supports active multi-lineage hematopoiesis in vitro: Functional implication of the biomimetic HSC niche. Int. J. Mol. Med. 2016, 38, 1141-1151. [CrossRef]

91. Vasko, T.; Frobel, J.; Lubberich, R.; Goecke, T.W.; Wagner, W. iPSC-derived mesenchymal stromal cells are less supportive than primary MSCs for co-culture of hematopoietic progenitor cells. J. Hematol. Oncol. 2016, 9, 43. [CrossRef]

92. Ludin, A.; Itkin, T.; Gur-Cohen, S.; Mildner, A.; Shezen, E.; Golan, K.; Kollet, O.; Kalinkovich, A.; Porat, Z.; D'Uva, G.; et al. Monocytes-macrophages that express $\alpha$-smooth muscle actin preserve primitive hematopoietic cells in the bone marrow. Nat. Immunol. 2012, 13, 1072-1082. [CrossRef]

93. Travnickova, J.; Chau, V.T.; Julien, E.; Mateos-Langerak, J.; Gonzalez, C.; Lelievre, E.; Lutfalla, G.; Tavian, M.; Kissa, K. Primitive macrophages control HSPC mobilization and definitive haematopoiesis. Nat. Commun. 2015, 6, 6227. [CrossRef]

94. Kang, Y.; Kim, S.; Khademhosseini, A.; Yang, Y. Creation of bony microenvironment with CaP and cell-derived ECM to enhance human bone-marrow MSC behavior and delivery of BMP-2. Biomaterials 2011, 32, 6119-6130. [CrossRef]

95. Datta, N.; Pham, Q.P.; Sharma, U.; Sikavitsas, V.I.; Jansen, J.A.; Mikos, A.G. In vitro generated extracellular matrix and fluid shear stress synergistically enhance 3D osteoblastic differentiation. Proc. Natl. Acad. Sci. USA 2006, 103, 2488-2493. [CrossRef] [PubMed]

96. Bhat, A.; Hoch, A.I.; Decaris, M.L.; Leach, J.K. Alginate hydrogels containing cell-interactive beads for bone formation. FASEB J. 2013, 27, 4844-4852. [CrossRef] [PubMed]

97. Jakubikova, J.; Cholujova, D.; Hideshima, T.; Gronesova, P.; Soltysova, A.; Harada, T.; Joo, J.; Kong, S.-Y.; Szalat, R.E.; Richardson, P.G.; et al. A novel 3D mesenchymal stem cell model of the multiple myeloma bone marrow niche: Biologic and clinical applications. Oncotarget 2016, 7, 77326-77341. [CrossRef] [PubMed]

98. Torisawa, Y.-S.; Spina, C.S.; Mammoto, T.; Mammoto, A.; Weaver, J.C.; Tat, T.; Collins, J.J.; Ingber, D.E. Bone marrow-on-a-chip replicates hematopoietic niche physiology in vitro. Nat. Methods 2014, 11, $663-669$. [CrossRef] [PubMed]

99. Rijal, G.; Bathula, C.; Li, W. Application of Synthetic Polymeric Scaffolds in Breast Cancer 3D Tissue Cultures and Animal Tumor Models. Int. J. Biomater. 2017, 2017, 8074890. [CrossRef] [PubMed]

100. Kim, T.-E.; Kim, C.G.; Kim, J.S.; Jin, S.; Yoon, S.; Bae, H.-R.; Kim, J.-H.; Jeong, Y.H. Three-dimensional culture and interaction of cancer cells and dendritic cells in an electrospun nano-submicron hybrid fibrous scaffold. Int. J. Nanomed. 2016, 11, 823-835. [CrossRef]

101. Campbell, J.J.; Husmann, A.; Hume, R.D.; Watson, C.J.; Cameron, R.E. Development of three-dimensional collagen scaffolds with controlled architecture for cell migration studies using breast cancer cell lines. Biomaterials 2017, 114, 34-43. [CrossRef]

102. Iwasaki, H.; Suda, T. Cancer stem cells and their niche. Cancer Sci. 2009, 100, 1166-1172. [CrossRef]

103. Gattazzo, F.; Urciuolo, A.; Bonaldo, P. Extracellular matrix: A dynamic microenvironment for stem cell niche. Biochim. Biophys. Acta (BBA) Gen. Subj. 2014, 1840, 2506-2519. [CrossRef]

104. Melzer, C.; Yang, Y.; Hass, R. Interaction of MSC with tumor cells. Cell Commun. Signal. 2016, 14, 1-12. [CrossRef]

105. Zhou, H.-S.; Carter, B.Z.; Andreeff, M. Bone marrow niche-mediated survival of leukemia stem cells in acute myeloid leukemia: Yin and Yang. Cancer Biol. Med. 2016, 13, 248-259. [CrossRef] [PubMed] 
106. Konopleva, M.Y.; Jordan, C.T. Leukemia Stem Cells and Microenvironment: Biology and Therapeutic Targeting. J. Clin. Oncol. 2011, 29, 591-599. [CrossRef] [PubMed]

107. Quail, D.F.; Joyce, J.A. Microenvironmental regulation of tumor progression and metastasis. Nat. Med. 2013, 19, 1423-1437. [CrossRef] [PubMed]

108. Konopleva, M.; Konoplev, S.; Hu, W.; Zaritskey, A.Y.; Afanasiev, B.V.; Andreeff, M. Stromal cells prevent apoptosis of AML cells by up-regulation of anti-apoptotic proteins. Leukemia 2002, 16, 1713-1724. [CrossRef] [PubMed]

109. Andreeff, M.; Zeng, Z.; Tabe, Y.; Samudio, I.; Fiegl, M.; Watt, J.; Dietrich, M.; Mcqueen, T.; Frolova, O.; Battula, L. Microenvironment and leukemia: Ying and Yang. Ann. Hematol. 2008, 87, S94-S98.

110. Tabe, Y.; Konopleva, M.Y. Advances in understanding the leukaemia microenvironment. Br. J. Haematol. 2014, 164, 767-778. [CrossRef]

111. Houshmand, M.; Soleimani, M.; Atashi, A.; Saglio, G.; Abdollahi, M.; Zarif, M.N. Mimicking the Acute Myeloid Leukemia Niche for Molecular Study and Drug Screening. Tissue Eng. Part C Methods 2017, 23, 72-85. [CrossRef]

112. Blanco, T.M.; Mantalaris, A.; Bismarck, A.; Panoskaltsis, N. The development of a three-dimensional scaffold for ex vivo biomimicry of human acute myeloid leukaemia. Biomaterials 2010, 31, 2243-2251. [CrossRef]

113. Kim, J.; Koo, B.-K.; Knoblich, J.A. Human organoids: Model systems for human biology and medicine. Nat. Rev. Mol. Cell Biol. 2020, 2020, 571-584. [CrossRef]

114. Fujihara, K.; Kotaki, M.; Ramakrishna, S. Guided bone regeneration membrane made of polycaprolactone/calcium carbonate composite nano-fibers. Biomaterials 2005, 26, 4139-4147. [CrossRef]

115. Park, S.A.; Lee, H.-J.; Kim, K.-S.; Lee, S.J.; Lee, J.-T.; Kim, S.-Y.; Chang, N.-H.; Park, S.-Y. In Vivo Evaluation of 3D-Printed Polycaprolactone Scaffold Implantation Combined with $\beta$-TCP Powder for Alveolar Bone Augmentation in a Beagle Defect Model. Materials 2018, 11, 238. [CrossRef] [PubMed]

116. Grassi, L.; Alfonsi, R.; Francescangeli, F.; Signore, M.; De Angelis, M.L.; Addario, A.; Costantini, M.; Flex, E.; Ciolfi, A.; Pizzi, S.; et al. Organoids as a new model for improving regenerative medicine and cancer personalized therapy in renal diseases. Cell Death Dis. 2019, 10, 1-15. [CrossRef] [PubMed]

117. Albrektsson, T.; Johansson, C. Osteoinduction, osteoconduction and osseointegration. Eur. Spine J. 2001, 10, S96-S101. [CrossRef] [PubMed]

118. Zaky, S.H.; Cancedda, R. Engineering Craniofacial Structures: Facing the Challenge. J. Dent. Res. 2009, 88, 1077-1091. [CrossRef] [PubMed]

119. Lee, S.J.; Lim, G.J.; Lee, J.-W.; Atala, A.; Yoo, J.J. In vitro evaluation of a poly(lactide-co-glycolide)-collagen composite scaffold for bone regeneration. Biomaterials 2006, 27, 3466-3472. [CrossRef]

120. Zhu, Y.; Wan, Y.; Zhang, J.; Yin, D.; Cheng, W. Manufacture of layered collagen/chitosan-polycaprolactone scaffolds with biomimetic microarchitecture. Colloids Surf. B Biointerfaces 2014, 113, 352-360. [CrossRef]

121. Zhang, S.; Chen, L.; Jiang, Y.Z.; Cai, Y.; Xu, G.; Tong, T.; Zhang, W.; Wang, L.; Ji, J.; Shi, P.; et al. Bi-layer collagen/microporous electrospun nanofiber scaffold improves the osteochondral regeneration. Acta Biomater. 2013, 9, 7236-7247. [CrossRef]

122. Kanungo, B.P.; Gibson, L.J. Density-property relationships in collagen-glycosaminoglycan scaffolds. Acta Biomater. 2010, 6, 344-353. [CrossRef]

123. Li, Z.; Ramay, H.R.; Hauch, K.D.; Xiao, D.; Zhang, M. Chitosan-alginate hybrid scaffolds for bone tissue engineering. Biomaterials 2005, 26, 3919-3928. [CrossRef]

124. Taylor, M.S.; Daniels, A.U.; Andriano, K.P.; Heller, J. Six bioabsorbable polymers:In vitro acute toxicity of accumulated degradation products. J. Appl. Biomater. 1994, 5, 151-157. [CrossRef]

125. Munaz, A.; Vadivelu, R.K.; John, J.S.; Barton, M.; Kamble, H.; Nguyen, N.-T. Three-dimensional printing of biological matters. J. Sci. Adv. Mater. Devices 2016, 1, 1-17. [CrossRef]

126. Lewis, E.E.L.; Wheadon, H.; Lewis, N.; Yang, J.; Mullin, M.; Hursthouse, A.; Stirling, D.; Dalby, M.J.; Berry, C.C. A Quiescent, Regeneration-Responsive Tissue Engineered Mesenchymal Stem Cell Bone Marrow Niche Model via Magnetic Levitation. ACS Nano 2016, 10, 8346-8354. [CrossRef] [PubMed]

127. Bumpers, H.L.; Janagama, D.G.; Manne, U.; Basson, M.D.; Katkoori, V. Nanomagnetic levitation three-dimensional cultures of breast and colorectal cancers. J. Surg. Res. 2015, 194, 319-326. [CrossRef] [PubMed]

128. Russo, T.; D’Amora, U.; Gloria, A.; Tunesi, M.; Sandri, M.; Rodilossi, S.; Albani, D.; Forloni, G.; Giordano, C.; Cigada, A.; et al. Systematic Analysis of Injectable Materials and 3D Rapid Prototyped Magnetic Scaffolds: From CNS Applications to Soft and Hard Tissue Repair/Regeneration. Procedia Eng. 2013, 59, 233-239. [CrossRef]

129. Kim, J.; Lee, H.; Selimović, Š.; Gauvin, R.; Bae, H. Organ-On-A-Chip: Development and Clinical Prospects Toward Toxicity Assessment with an Emphasis on Bone Marrow. Drug Saf. 2015, 38, 409-418. [CrossRef] 
130. Schmal, O.; Seifert, J.; Schäffer, T.E.; Walter, C.B.; Aicher, W.K.; Klein, G. Hematopoietic Stem and Progenitor Cell Expansion in Contact with Mesenchymal Stromal Cells in a Hanging Drop Model Uncovers Disadvantages of 3D Culture. Stem Cells Int. 2016, 2016, 4148093. [CrossRef]

131. Smith, A. Embryo-Derived Stem Cells: Of Mice and Men. Annu. Rev. Cell Dev. Biol. 2001, 17, 435-462. [CrossRef]

132. Bhatia, S.N.; Ingber, D.E. Microfluidic organs-on-chips. Nat. Biotechnol. 2014, 32, 760-772. [CrossRef]

133. Rice, W.L.; Kaplan, D.L.; Georgakoudi, I. Quantitative biomarkers of stem cell differentiation based on intrinsic two-photon excited fluorescence. J. Biomed. Opt. 2007, 12, 060504. [CrossRef]

134. Georgakoudi, I.; Rice, W.L.; Hronik-Tupaj, M.; Kaplan, D.L. Optical Spectroscopy and Imaging for the Noninvasive Evaluation of Engineered Tissues. Tissue Eng. Part B Rev. 2008, 14, 321-340. [CrossRef]

135. Quinn, K.P.; Bellas, E.; Fourligas, N.; Lee, K.; Kaplan, D.L.; Georgakoudi, I. Characterization of metabolic changes associated with the functional development of 3D engineered tissues by non-invasive, dynamic measurement of individual cell redox ratios. Biomaterials 2012, 33, 5341-5348. [CrossRef] [PubMed]

136. Rice, W.L.; Kaplan, D.L.; Georgakoudi, I. Two-Photon Microscopy for Non-Invasive, Quantitative Monitoring of Stem Cell Differentiation. PLoS ONE 2010, 5, e10075. [CrossRef] [PubMed]

137. Amini, A.R.; Laurencin, C.T.; Nukavarapu, S.P. Bone Tissue Engineering: Recent Advances and Challenges. Crit. Rev. Biomed. Eng. 2012, 40,363-408. [CrossRef] [PubMed]

138. Reizabal, A.; Brito-Pereira, R.; Fernandes, M.M.; Castro, N.; Correia, V.; Ribeiro, C.; Costa, C.; Perez, L.; Vilas, J.L.; Lanceros-Méndez, S. Silk Fibroin magnetoactive nanocomposite films and membranes for dynamic bone tissue engineering strategies. Materialia 2020, 12, 100709. [CrossRef]

Publisher's Note: MDPI stays neutral with regard to jurisdictional claims in published maps and institutional affiliations. 